\title{
New Tumor Biomarkers in Ovarian Cancer and Its Prognostic and Clinical Relevance
}

\author{
Malgorzata Banys ${ }^{1,2}$, Natalia Krawczyk ${ }^{1}$ and Tanja Fehm ${ }^{1}$ \\ ${ }^{1}$ Department of Obstetrics and Gynecology, University of Tuebingen, Tuebingen, \\ 2Department of Obstetrics and Gynecology, Marienkrankenhaus Hamburg, Hamburg
}

Germany

\section{Introduction}

In Europe and the United States, ovarian cancer is currently the major cause of death from gynecological malignancy. Up to $60 \%$ ovarian cancer patients die from locally advanced disease. Nonetheless, even patients treated with optimal cytoreduction may subsequently suffer from metastatic disease. Since treatment strategies are developed to control locoregional cancer growth, it may be anticipated that more patients will die of distant metastases. The lack of early disease signals further contributes to the fact that only onefourth of ovarian cancers are identified at stage I. Ovarian cancer remains thus undetected due to late symptoms and the lack of reliable and clinically applicable screening tools. Further, the identification of new biomarkers could optimize prediction and monitoring of anticancer therapies and provide insights into ovarian cancer progression.

Presence of disseminated tumor cells (DTC) in bone marrow is a common phenomenon observed in solid epithelial tumors. As shown by a multi-center analysis of bone marrow (BM) specimens from more than 4,700 patients, DTC detection at the time of breast cancer diagnosis is strongly correlated with poor clinical outcome (level-I-evidence) [1]. There is growing evidence that hematogenous tumor cell dissemination may occur in other tumors, such as prostate, colon and gynecologic malignancies. DTC, as surrogate parameter for occult hematogenous spread, are routinely detected in $22-51 \%$ ovarian cancer patients. Interestingly, ovarian metastases to the bone are only rarely observed [2], [3], [4]. Whether bone marrow serves in these patients as a temporary compartment from where persistent DTC are able to migrate, remains unclear. It has been demonstrated that dissemination of isolated tumor cells to secondary sites occurs as early as in FIGO stage I disease [4]. Single tumor cells acquire thus the potential to disseminate to extraperitoneal compartments early in the process of the disease.

Of all prognostic factors, monitoring of minimal residual disease is the only one available after the tumor has been removed. Beside monitoring of tumor markers, there is currently a major effort to identify other biological markers which can be assessed with minimally invasive methods and persist beyond surgery. We previously reported on a significant correlation of positive bone marrow status with shortened relapse-free survival in ovarian cancer patients [5]. DTC persistence after completion of platinum-based chemotherapy was also found to be prognostically relevant [6]. Further, the identification of molecular biomarkers may represent excellent targets for new treatment strategies for chemoresistant 
ovarian cancer patients. Recently, attempts have been made to target DTC by using antibody-based therapy with catumaxomab [7]. However, data on DTC detection in gynecological malignancies are so far limited [4], [8], [9], [10], [11].

In the following chapter, we discuss new biomarkers and circulating tumor cells. Data on prognostic and clinical relevance are presented.

\section{Disseminated and circulating tumor cells in ovarian cancer}

High mortality in patients with ovarian malignancies is mostly due to their locally advanced tumor rather than to distant metastatic disease. According to autopsy studies, however, occult metastatic tumors are encountered frequently at distant sites (e.g. liver, lung, bone, central nervous system) [3]. Up to $38 \%$ of patients with ovarian cancer developed metastases consistent with Stage IV disease at some time during the natural history of their disease. These results suggest that hematogenous dissemination of single tumor cells is a phenomenon much more common than would be expected from the clinical course of the disease.

Numerous techniques have been developed to isolate and quantify disseminated tumor cells in epithelial carcinomas. So far, no specific antigen or marker gene has been described for ovarian cancer. Therefore, the most widely used DTC detection assays rely on antibodybased capture of tumor cells, which express epithelial markers that are absent from normal leukocytes (Figure 1). Commonly targeted antigens are cytokeratin and EpCAM because their expression is relatively constant and universal in cells of epithelial origin $[2,6,11]$.

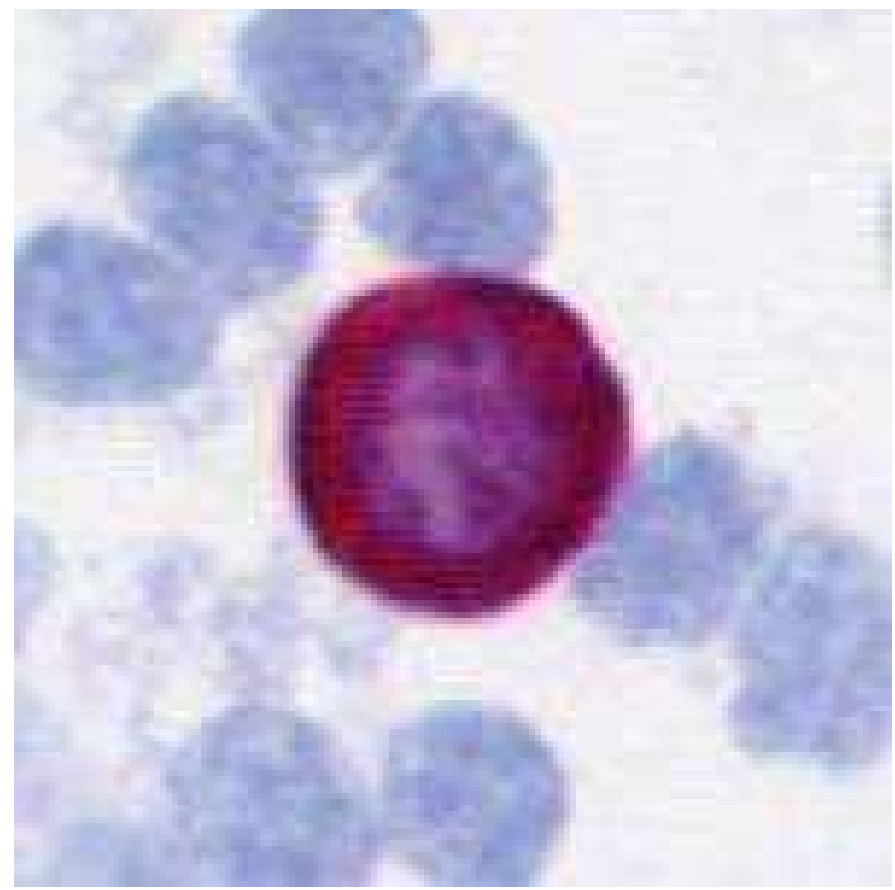

Fig. 1. Disseminated tumor cell from ovarian cancer patient with typical cytomorphology and immunophenotype (positive cytokeratin-staining, large nucleus, high nuclear to cytoplasmic ratio, nucleus partially covered by CK-staining, nucleus granular [12]. 
Disseminated tumor cells can be detected in $22-51 \%$ of ovarian cancer patients stage FIGO IIII $[2,4,6,11]$. This relatively high incidence suggests that single tumor cells acquire the potential to disseminate to secondary sites outside the peritoneum early in the course of the disease, and that blood-borne dissemination in ovarian malignancy is a common rather than random occurrence. The number of detected cytokeratin-positive cells generally ranges in bone marrow from 1 to 30 per $2 \times 10^{6}$ mononuclear cells $[5,6]$.

The influence of primary tumor's characteristics on DTC presence is unclear. Based on a group of 108 primary ovarian cancer patients, Braun et al. reported no correlation between classical prognostic factors, such as FIGO stage, tumor type, residual intraperitoneal tumor, the presence of ascites, peritoneal metastasis or lymph node involvement, and DTC status [4]. The only parameter associated with BM positivity was grading $(p=0.02)$. In a study collective of 112 patients, we could confirm this observation [5]. Similar results were reported by others $[6,10,11,13]$.

\subsection{Prognostic relevance of DTC/CTC in ovarian cancer}

For ovarian cancer, there is only limited data on prognostic value of DTC detection (Table 1). Braun et al. reported reduced distant disease-free survival in patients with detectable DTC at the time of diagnosis [4]. This correlation was confirmed in a subgroup of 64 optimally debulked patients, which indicated the importance of bone marrow status in patients who received successful surgical cytoreduction. We previously demonstrated that DTC positivity affects disease-free survival in a group of 112 ovarian cancer patients stage FIGO I-III [5]. Interestingly, positive DTC status was also an indicator for early local recurrence which is mostly due to suboptimal tumor debulking surgery and abdominal spread. Therefore, it might be speculated that DTC are indicators of a more aggressive phenotype of the primary disease that is likely to cause local recurrence. In contrast, other authors reported no

\begin{tabular}{|l|c|c|c|c|}
\hline Author & N & Method & $\begin{array}{c}\text { Median } \\
\text { follow-up } \\
\text { [months] }\end{array}$ & $\begin{array}{c}\text { Prognostic } \\
\text { significance }\end{array}$ \\
\hline Banys [5] & 112 & DTC (ICC) & 12 & DFS \\
\hline Braun [4] & 108 & DTC (ICC) & 45 & DFS \\
\hline Aktas [13] & 95 & DTC (ICC) & 28 & n.s. \\
\hline Fehm [2] & 69 & DTC (ICC) & 5 & n.s. \\
\hline Schindlbeck [11] & 90 & DTC (ICC) & 28 & DDFS \\
\hline Marth [10] & 73 & DTC (immunobeads) & 25 & n.s. \\
\hline Wimberger [16] & 62 & DTC (ICC) & 18 & DFS 1 \\
\hline Cain [14] & 50 & DTC (ICC) & & n.s. \\
\hline Wimberger et al. [6] & 30 & DTC (ICC) & $18^{2}$ & PFS \\
\hline
\end{tabular}

Abbreviations: DFS - disease-free survival, DDFS - distant disease-free survival, DTC - disseminated tumor cells in bone marrow, ICC - immunocytochemistry, n.s. - not significant, PFS - progression-free survival

${ }^{1}$ DTC detected after chemotherapy

2 Mean

Table 1. Prognostic relevance of disseminated tumor cells and other biomarkers in ovarian cancer. 
significant correlation between bone marrow status and survival in ovarian cancer patients $[10,14]$. One possible explanation for this discrepancy might be the time point of bone marrow aspiration. For instance, Marth et al. showed no association between the presence of tumor cells in BM and survival [10]. However, all samples were collected after surgery, whereas other authors aspirated BM immediately preoperatively [4, 5]. A transient dissemination of cancer cells from the primary tumor due to intraoperative manipulation could contribute to false-positive results and therefore affect further analysis [15].

\subsection{Circulating tumor cells}

One limitation of bone marrow sampling is its invasiveness. Since BM biopsy is not well tolerated by many patients, translational research have focused increasingly on circulating tumor cell (CTC) detection in the blood. In breast cancer, a significant impact of CTC detection on survival has already been established both in primary and metastatic situation $[17,18]$. Currently, two commercially available kits for CTC detection in breast cancer are in use: antibody-based CellSearch and Multiplex-RT-PCR AdnaTest. Both tests were modified and validated in ovarian cancer patients (Table 2). The largest trial so far is the recently published study by Poveda et al. including 216 patients diagnosed with relapsed ovarian cancer [19]. Elevated numbers of CTC (> 1 cell / $7.5 \mathrm{ml}$ blood) detected by the CellSearch assay before start of therapy predicted unfavorable prognosis. Aktas et al. used a modified AdnaTest assay to isolate cells expressing EpCAM, MUC-1, HER-2 or CA 125transcripts [13]. Patients with detectable CTC has significantly shorter survival, irrespective of time point of blood sampling (before surgery or after chemotherapy). Further, Fan et al. examined 66 primary ovarian patients using a cell invasion assay and reported a significant decrease in disease-free survival in CTC-positive ovarian patients

\begin{tabular}{|c|c|c|c|c|}
\hline Author & $\mathbf{N}$ & Method & $\begin{array}{l}\text { Median } \\
\text { follow-up } \\
\text { [months] }\end{array}$ & $\begin{array}{l}\text { Prognostic } \\
\text { significance }\end{array}$ \\
\hline Poveda [19] & 216 & CTC (ICC: CellSearch) ${ }^{1}$ & & PFS, OS \\
\hline Sehouli [8] & 167 & CTC (ICC) & 46 & n.s. \\
\hline Marth [10] & 90 & CTC (immunomagnetic beads) & 25 & n.s. \\
\hline Aktas [13] & 86 & CTC (Multiplex-RT-PCR: AdnaTest) & 28 & $\mathrm{OS}^{2}$ \\
\hline Heubner [23] & 68 & Circulating 20S-proteasomes & 19 & OS \\
\hline Fan [20] & 66 & $\begin{array}{c}\text { CTC (immunofluorescence, cell } \\
\text { invasion assay) }\end{array}$ & 18 & DFS \\
\hline Wimberger [16] & 62 & $\begin{array}{l}\text { Circulating nucleosomes, DNA, } \\
\text { protease and caspase activity }\end{array}$ & 18 & DFS, OS \\
\hline Judson [24] & 53 & CTC (ICC) & $19^{3}$ & n.s. \\
\hline
\end{tabular}

Abbreviations: CTC - circulating tumor cells in peripheral blood, DFS - disease-free survival, ICC immunocytochemistry, n.s. - not significant, PFS - progression-free survival

${ }^{1}$ Relapsed ovarian cancer

${ }^{2}$ Both before and after chemotherapy

${ }^{3}$ Mean

Table 2. Prognostic relevance of circulating tumor cells in ovarian cancer. 
[20]. In contrast, Marth et al. reported a 12\% incidence throughout all tumor stages but observed no correlation with clinical outcome [10]. Interestingly, positive finding in the blood was highly associated with DTC detection in bone marrow. Smaller studies showed varying CTC incidence, depending on methodology [21, 22].

\subsection{Therapy monitoring}

Beyond the prognostic value of DTC detection, monitoring of minimal residual disease following treatment represent a promising parameter for the assessment of residual risk of relapse. Tumor markers such as CA125 are clinically accepted tools for therapy monitoring in advanced ovarian cancer. Nevertheless, CA125 levels generally decline rapidly during chemotherapy and are mostly below cut-off level at the end of treatment even though a significant proportion of patients will face a relapse of the disease within five years. Moreover, the clinical utility of serial CA125 measurements for early therapy of a relapse is currently controversially debated [25]. In this context, the presence of isolated tumor cells in bone marrow and possibly in peripheral blood, might indicate occult tumor load after first line therapy and serve as a parameter for suboptimal response to therapy. For other tumor entities, such as breast cancer, DTC persistence after treatment is an independent indicator of reduced clinical outcome [26]. Whether therapy-resistant DTC also affect survival in ovarian cancer, is a subject of current studies. Wimberger et al. correlated changes in DTC counts before and after first-line chemotherapy to clinical course of disease in 30 ovarian cancer patients. DTC persistence was observed in half of the patients after chemotherapy. Patients with marked increase in DTC numbers had significantly shortened progression-free survival [6].

So far, assessment of therapy efficacy in asymptomatic ovarian cancer patients after completion of standard chemotherapy has not been possible until patient's eventual relapse. A reliable therapy monitoring tool could identify high-risk patients in need of additional therapy. Whether persistent DTC, as surrogate parameter of minimal residual disease, may be targeted by secondary adjuvant therapy is currently under investigation and should be further studied.

\subsection{Stem cell hypothesis}

As to progression of ovarian cancer, an interesting hypothesis has been introduced recently. According to 'classical' model of carcinogenesis, any cell may be source of malignant transformation and lead to tumor growth. However, emerging evidence has suggested that the capability of cancer to grow, proliferate and eventually relapse is dependent on a small subpopulation of tumor cells, called cancer stem cells (CSC). These cells are considered especially significant on the background of drug resistance, tumor dormancy, minimal residual disease, and disease recurrence. Several cancer entities, such as ovarian cancer, retinoblastoma, gastrointestinal and breast cancer might arise from a small population of cells with stem cell properties that sustain tumor formation and growth [27]. This 'stem cell hypothesis' assumes an important role of tumor-initiating progenitor cells in tumor progression. Accordingly, cancer stem cells, but not the remaining cells in the primary tumor, have the ability to self-renew, propagate tumorigenesis and are drug-resistant [28]. Ovarian cancer cell lines were demonstrated to feature "side population" cells with ability to differentiate into cancers with different histologies, similar to the assumed pluripotent 
character of stem cells [29]. Such cells has been detected in various solid tumors, such as colon [30], breast [31] and ovarian cancer [32-34]. Based on animal models and natural course of the disease (e.g. high recurrence rates, multidrug resistance), it has been postulated that cancer stem cells play a crucial role in ovarian cancer [32, 35]. Szotek et al. detected side population (SP) not only in human ovarian cancer cell lines, but also in primary ascites cancer cells [32]. Hosonuma et al. analyzed 28 samples obtained from ovarian cancer patients with respect to the expression of SP as a marker for the presence of cancer stem cells [29]. Side population was encountered more often in recurrent and metastatic patients and SP+ patients had significantly reduced survival. Further, although advanced ovarian cancer mostly initially responds to platinum-based combination treatment, it is usually followed by the chemotherapy-resistant phenotype. One possible explanation for this phenomenon is the CSC-induced drug-resistance: standard therapies fail to target tumor-initiating cells [32]. Recently, cisplatin chemotherapy has been shown to generate residual cells with mesenchymal stem cell-like characteristics in vitro [36]. Therefore, these cells need to be targeted with different approaches by identification of specific antigens. However, very few tumor antigens have been described to target the CSC subpopulation.

One currently debated hypothesis is the theory that disseminated and circulating tumor cells, the surrogate marker for minimal residual disease and possibly precursor of systemic metastasis, are cancer stem cells. In breast cancer, Balic et al. reported that early DTC express stem cell phenotype [37] and circulating tumor cells often exhibit epithelialmesenchymal transition markers [31]. In addition, Abraham et al. has shown that a high percentage of $\mathrm{CD} 44+/ \mathrm{CD} 24$ - cells in the primary tumor correlate with a higher prevalence of distant metastasis [38]. Since the majority of CTC in breast cancer are triple-negative, irrespective of primary tumor's phenotype [39], we may assume that some of these cells reflect stem cell-like subpopulation. This issue, however, has not been studied in ovarian cancer. Whether isolated tumor cells in extraperitoneal sites, such as blood and bone marrow, are in fact ovarian cancer stem cells, remains yet to be cleared.

\section{Novel biomarkers in ovarian cancer}

To date, the only tumor marker that has proven to detect ovarian cancer prior to the onset of clinical symptoms and is commonly used in clinical practice is CA125 [40]. However, numerous other biomarkers have been developed over the years and are currently being tested for their usefulness as screening, prognostic or therapy monitoring tools.

\subsection{Osteopontin}

Osteopontin (OPN) is a cell surface and secretory glycoprotein containing an arginineglycine-aspartate motif and is one of the candidate markers identified by high-throughput cDNA microarray techniques. Osteopontin plays a critical role in cellular proliferation, metastasis and apoptosis. Preoperative plasma levels are significantly higher in ovarian cancer patients than in women with benign tumors or in healthy women [41]. OPN levels also seem to correlate with stage of disease. It has been speculated that OPN may complement CA125 expression in a marker panel for recurrence monitoring $[42,43]$. When combined with CA125, OPN reaches high sensitivity of $94 \%$. Further, like other cell-surface 
proteins, OPN may serve as a potential target for the antibody-based therapies. In vitro, humanized anti-osteopontin antibody, hu1A12, was effective in inhibiting the cell adhesion, migration, invasion and colony formation and may be a promising therapeutic agent in breast cancer, and possibly other tumor entities, including ovarian cancer, as well [44].

\subsection{Haptoglobin}

In a manner similar to other acute phase proteins, increased levels of haptoglobin are observed in inflammatory processes, infections and various cancers, including breast, lung and bladder cancers [45]. Elevation of haptoglobin in blood of ovarian cancer patients has been reported in several studies [46-48]. Zhao et al. has shown that elevated haptoglobin at the time of diagnosis is associated with reduced overall survival in a multivariate analysis [45].

\subsection{Human Epididymis Protein 4 (HE4)}

Human Epididymis Protein 4 is a stable disulfide core protein associated with the WFDC2 gene that is overexpressed in ovarian cancer, particularly serous and endometrioid histologies. Serum HE4 levels were found to be elevated in ovarian cancer patients in numerous studies [49]. Conclusive data on the feasibility as a screening assay is pending. Holcomb et al. reported a superior specificity of HE4 compared to CA125 for the identification of malignant adnexal masses [50]. An evaluation of a marker panel ROMA (Risk of Ovarian Malignancy Algorithm) utilizing CA125 and HE4 initially yielded promising results [51]. However, subsequent validation in clinical setting did not confirm any benefit compared to use of CA125 alone [52, 53]. As to prognostic relevance, Peak et al. have shown that an elevated serum HE4 level was associated with reduced progression-free survival [54].

\subsection{Mesothelin}

Mesothelin is a cell surface glycoprotein that is present on normal mesothelial cells and overexpressed in mesothelioma, ovarian cancer and other malignant tumors [55-57]. As a screening tool, mesothelin was shown to perform comparably to CA125 and might improve cancer detection as a combined marker panel [58].

\section{$3.5 \mathrm{~B} 7-\mathrm{H} 4$}

$\mathrm{B} 7-\mathrm{H} 4$ is one of the B7 family members that serve as negative regulators of $\mathrm{T}$ cell function. Its overexpression promotes cellular transformation and has been shown in a variety of cancers. Elevated levels of B7-H4 are detected in early-stage ovarian cancer [59].

\subsection{Additional markers}

Numerous other biomarkers, such as prostasin, VEGF, macrophage colony stimulating factor, kallikrein 6 and 10, mucin 1, interleukins 6 and 8, apolipoprotein A1, OVX1 and many others, have been identified and yielded promising results [60, 61]. In 2009, the U.S. Food and Drug Administration approved the blood test panel OVA1 for the preoperative assessment of pelvic masses [62]. OVA1 incorporates five markers: CA125-II, transferrin, transthyretin, apolipoprotein AI, and beta 2 microglobulin. To date, none of the currently discussed novel markers has a real potential to replace CA125 in clinical routine. 


\begin{tabular}{|c|c|c|c|c|}
\hline Biomarker & Function & $\begin{array}{c}\text { Useful as a } \\
\text { screening } \\
\text { tool }\end{array}$ & $\begin{array}{c}\text { Useful for } \\
\text { therapy } \\
\text { monitoring }\end{array}$ & $\begin{array}{l}\text { Clinical } \\
\text { relevance }\end{array}$ \\
\hline Osteopontin & $\begin{array}{l}\text { Cell surface protein; } \\
\text { plays a role in } \\
\text { cellular } \\
\text { proliferation, } \\
\text { metastasis and } \\
\text { apoptosis }\end{array}$ & $\begin{array}{c}\text { Low } \\
\text { specificity; } \\
\text { possibly } \\
\text { useful in } \\
\text { combination } \\
\text { with CA125 } \\
{[41,43]} \\
\end{array}$ & $\begin{array}{c}\text { Possibly yes; in } \\
\text { combination } \\
\text { with CA125 } \\
{[42]}\end{array}$ & $\begin{array}{l}\text { Limited data on } \\
\text { prognostic } \\
\text { relevance [63]; } \\
\text { possible use in } \\
\text { targeted } \\
\text { therapy [44, 64] }\end{array}$ \\
\hline Haptoglobin & Acute phase protein & $\begin{array}{l}\text { Low } \\
\text { specificity } \\
{[46,48]}\end{array}$ & $\begin{array}{c}\text { Unclear; } \\
\text { mostly } \\
\text { decrease } \\
\text { during } \\
\text { chemotherapy } \\
\text { [47] } \\
\end{array}$ & $\begin{array}{c}\text { Prognostic } \\
\text { relevance - yes } \\
\text { (data from small } \\
\text { studies) [45] }\end{array}$ \\
\hline $\begin{array}{l}\text { Human } \\
\text { epididymis } \\
\text { protein } 4\end{array}$ & $\begin{array}{c}\text { Secreted } \\
\text { glycoprotein }\end{array}$ & $\begin{array}{l}\text { Unclear due } \\
\text { to partly } \\
\text { contradictory } \\
\text { results }[50, \\
52,65]\end{array}$ & $\begin{array}{c}\text { No conclusive } \\
\text { data }\end{array}$ & $\begin{array}{c}\text { Prognostic } \\
\text { relevance - yes } \\
\text { (data from small } \\
\text { studies) [54] }\end{array}$ \\
\hline Mesothelin & $\begin{array}{l}\text { Surface antigen of } \\
\text { mesothelial cells }\end{array}$ & $\begin{array}{c}\text { Not superior } \\
\text { to CA125, } \\
\text { however use } \\
\text { in } \\
\text { combination } \\
\text { with CA125 } \\
\text { possible [58] }\end{array}$ & $\begin{array}{c}\text { No conclusive } \\
\text { data }\end{array}$ & $\begin{array}{l}\text { Possible use in } \\
\text { targeted } \\
\text { therapy }[66,67]\end{array}$ \\
\hline B7-H4 & $\begin{array}{l}\text { Negative regulator } \\
\text { of } \mathrm{T} \text { cell function }\end{array}$ & $\begin{array}{c}\text { Possibly yes } \\
\text { in } \\
\text { combination } \\
\text { with CA125 } \\
\text { [59] }\end{array}$ & $\begin{array}{c}\text { No conclusive } \\
\text { data }\end{array}$ & $\begin{array}{l}\text { No prognostic } \\
\text { value }[59,68]\end{array}$ \\
\hline
\end{tabular}

Table 3. Novel biomarkers in ovarian cancer and their potential impact on diagnostics and therapy.

\section{Conclusions}

Despite advances in diagnostics and therapy, $60 \%$ of women diagnosed with ovarian cancer will eventually suffer from a relapse, resulting in a poor overall survival. Currently, efficacy of therapy is evaluated by physical examinations, radiographic imaging, and evaluation of CA125 levels. There continues to be a need to identify new biomarkers for better prediction and prognostication.

Early hematogenous tumor cell dissemination is a common phenomenon in solid epithelial cancers. There is growing evidence that detection of single tumor cells in blood or bone marrow of ovarian cancer patients is associated with reduced clinical outcome. Whether 
these patients benefit from a more aggressive or prolonged treatment remains to be evaluated.

\section{References}

[1] Braun S, Vogl FD, Naume B, Janni W, Osborne MP, Coombes RC, Schlimok G, Diel IJ, Gerber B, Gebauer G et al: A pooled analysis of bone marrow micrometastasis in breast cancer. N Engl J Med 2005, 353(8):793-802.

[2] Fehm T, Becker S, Bachmann C, Beck V, Gebauer G, Banys M, Wallwiener D, Solomayer EF: Detection of disseminated tumor cells in patients with gynecological cancers. Gynecol Oncol 2006, 103(3):942-947.

[3] Dauplat J, Hacker NF, Nieberg RK, Berek JS, Rose TP, Sagae S: Distant metastases in epithelial ovarian carcinoma. Cancer 1987, 60(7):1561-1566.

[4] Braun S, Schindlbeck C, Hepp F, Janni W, Kentenich C, Riethmuller G, Pantel K: Occult tumor cells in bone marrow of patients with locoregionally restricted ovarian cancer predict early distant metastatic relapse. J Clin Oncol 2001, 19(2):368-375.

[5] Banys M, Solomayer EF, Becker S, Krawczyk N, Gardanis K, Staebler A, Neubauer H, Wallwiener D, Fehm T: Disseminated tumor cells in bone marrow may affect prognosis of patients with gynecologic malignancies. Int J Gynecol Cancer 2009, 19(5):948-952.

[6] Wimberger P, Heubner M, Otterbach F, Fehm T, Kimmig R, Kasimir-Bauer S: Influence of platinum-based chemotherapy on disseminated tumor cells in blood and bone marrow of patients with ovarian cancer. Gynecol Oncol 2007, 107(2):331-338.

[7] Wimberger P, Heubner M, Lindhofer H, Jager M, Kimmig R, Kasimir-Bauer S: Influence of catumaxomab on tumor cells in bone marrow and blood in ovarian cancer. Anticancer Res 2009, 29(5):1787-1791.

[8] Sehouli J, Konsgen D, Nimpsch R, Stengel D, Oskay G, Mustea A, Oertel J, Lichtenegger W: Prognostic significance of epithelial cells in the blood of patients with gynaecological malignancies. Anticancer Res 2003, 23(5b):4133-4140.

[9] Janni W, Hepp F, Strobl B, Rack B, Rjosk D, Kentenich C, Schindlbeck C, Hantschmann $\mathrm{P}$, Pantel K, Sommer $\mathrm{H}$ et al: Patterns of disease recurrence influenced by hematogenous tumor cell dissemination in patients with cervical carcinoma of the uterus. Cancer 2003, 97(2):405-411.

[10] Marth C, Kisic J, Kaern J, Trope C, Fodstad O: Circulating tumor cells in the peripheral blood and bone marrow of patients with ovarian carcinoma do not predict prognosis. Cancer 2002, 94(3):707-712.

[11] Schindlbeck C, Hantschmann P, Zerzer M, Jahns B, Rjosk D, Janni W, Rack B, Sommer $\mathrm{H}$, Friese K: Prognostic impact of KI67, p53, human epithelial growth factor receptor 2, topoisomerase IIalpha, epidermal growth factor receptor, and nm23 expression of ovarian carcinomas and disseminated tumor cells in the bone marrow. Int J Gynecol Cancer 2007.

[12] Fehm T, Braun S, Muller V, Janni W, Gebauer G, Marth C, Schindlbeck C, Wallwiener D, Borgen E, Naume B et al: A concept for the standardized detection of disseminated tumor cells in bone marrow from patients with primary breast cancer and its clinical implementation. Cancer 2006, 107(5):885-892. 
[13] Aktas B, Kasimir-Bauer S, Heubner M, Kimmig R, Wimberger P: Molecular profiling and prognostic relevance of circulating tumor cells in the blood of ovarian cancer patients at primary diagnosis and after platinum-based chemotherapy. Int J Gynecol Cancer 2011, 21(5):822-830.

[14] Cain JM, Ellis GK, Collins C, Greer BE, Tamimi HK, Figge DC, Gown AM, Livingston RB: Bone marrow involvement in epithelial ovarian cancer by immunocytochemical assessment. Gynecol Oncol 1990, 38(3):442-445.

[15] Camara O, Kavallaris A, Noschel H, Rengsberger M, Jorke C, Pachmann K: Seeding of epithelial cells into circulation during surgery for breast cancer: the fate of malignant and benign mobilized cells. World J Surg Oncol 2006, 4:67.

[16] Wimberger P, Roth C, Pantel K, Kasimir-Bauer S, Kimmig R, Schwarzenbach H: Impact of platinum-based chemotherapy on circulating nucleic acid levels, protease activities in blood and disseminated tumor cells in bone marrow of ovarian cancer patients. Int J Cancer 2010.

[17] Cristofanilli M, Budd GT, Ellis MJ, Stopeck A, Matera J, Miller MC, Reuben JM, Doyle GV, Allard WJ, Terstappen LW et al: Circulating tumor cells, disease progression, and survival in metastatic breast cancer. N Engl J Med 2004, 351(8):781-791.

[18] Rack BK, Schindlbeck C, Andergassen U, Schneeweiss A, Zwingers T, Lichtenegger W, Beckmann M, Sommer HL, Pantel K, Janni W: Use of circulating tumor cells (CTC) in peripheral blood of breast cancer patients before and after adjuvant chemotherapy to predict risk for relapse: The SUCCESS trial. ASCO Annual Meeting 2010. J Clin Oncol 2010, 28:15s (suppl; abstr 1003).

[19] Poveda A, Kaye SB, McCormack R, Wang S, Parekh T, Ricci D, Lebedinsky CA, Tercero JC, Zintl P, Monk BJ: Circulating tumor cells predict progression free survival and overall survival in patients with relapsed/recurrent advanced ovarian cancer. Gynecol Oncol 2011.

[20] Fan T, Zhao Q, Chen JJ, Chen WT, Pearl ML: Clinical significance of circulating tumor cells detected by an invasion assay in peripheral blood of patients with ovarian cancer. Gynecol Oncol 2009, 112(1):185-191.

[21] Ntouroupi TG, Ashraf SQ, McGregor SB, Turney BW, Seppo A, Kim Y, Wang X, Kilpatrick MW, Tsipouras $\mathrm{P}$, Tafas $\mathrm{T}$ et al: Detection of circulating tumour cells in peripheral blood with an automated scanning fluorescence microscope. Br J Cancer 2008, 99(5):789-795.

[22] Engel H, Kleespies C, Friedrich J, Breidenbach M, Kallenborn A, Schondorf T, Kolhagen $\mathrm{H}$, Mallmann P: Detection of circulating tumour cells in patients with breast or ovarian cancer by molecular cytogenetics. Br J Cancer 1999, 81(7):1165-1173.

[23] Heubner M, Wimberger P, Dahlmann B, Kasimir-Bauer S, Kimmig R, Peters J, Wohlschlaeger J, Sixt SU: The prognostic impact of circulating proteasome concentrations in patients with epithelial ovarian cancer. Gynecol Oncol 2011, 120(2):233-238.

[24] Judson PL, Geller MA, Bliss RL, Boente MP, Downs LS, Jr., Argenta PA, Carson LF: Preoperative detection of peripherally circulating cancer cells and its prognostic significance in ovarian cancer. Gynecol Oncol 2003, 91(2):389-394.

[25] Rustin GJ, van der Burg ME, Griffin CL, Guthrie D, Lamont A, Jayson GC, Kristensen G, Mediola C, Coens C, Qian W et al: Early versus delayed treatment of relapsed 
ovarian cancer (MRC OV05/EORTC 55955): a randomised trial. Lancet 2010, 376(9747):1155-1163.

[26] Janni W, Rack B, Schindlbeck C, Strobl B, Rjosk D, Braun S, Sommer H, Pantel K, Gerber $B$, Friese K: The persistence of isolated tumor cells in bone marrow from patients with breast carcinoma predicts an increased risk for recurrence. Cancer 2005, 103(5):884-891.

[27] Setoguchi T, Taga T, Kondo T: Cancer stem cells persist in many cancer cell lines. Cell Cycle 2004, 3(4):414-415.

[28] Dyall S, Gayther SA, Dafou D: Cancer stem cells and epithelial ovarian cancer. J Oncol 2010, 2010:105269.

[29] Hosonuma S, Kobayashi Y, Kojo S, Wada H, Seino K, Kiguchi K, Ishizuka B: Clinical significance of side population in ovarian cancer cells. Hum Cell 2011, 24(1):9-12.

[30] Ricci-Vitiani L, Lombardi DG, Pilozzi E, Biffoni M, Todaro M, Peschle C, De Maria R: Identification and expansion of human colon-cancer-initiating cells. Nature 2007, 445(7123):111-115.

[31] Aktas B, Tewes M, Fehm T, Hauch S, Kimmig R, Kasimir-Bauer S: Stem cell and epithelial-mesenchymal transition markers are frequently overexpressed in circulating tumor cells of metastatic breast cancer patients. Breast Cancer Res 2009, 11(4):R46.

[32] Szotek PP, Pieretti-Vanmarcke R, Masiakos PT, Dinulescu DM, Connolly D, Foster R, Dombkowski D, Preffer F, Maclaughlin DT, Donahoe PK: Ovarian cancer side population defines cells with stem cell-like characteristics and Mullerian Inhibiting Substance responsiveness. Proc Natl Acad Sci U S A 2006, 103(30):11154-11159.

[33] Bapat SA, Mali AM, Koppikar CB, Kurrey NK: Stem and progenitor-like cells contribute to the aggressive behavior of human epithelial ovarian cancer. Cancer Res 2005, 65(8):3025-3029.

[34] Challen GA, Little MH: A side order of stem cells: the SP phenotype. Stem Cells 2006, 24(1):3-12.

[35] Ponnusamy MP, Batra SK: Ovarian cancer: emerging concept on cancer stem cells. J Ovarian Res 2008, 1(1):4.

[36] Latifi A, Abubaker K, Castrechini N, Ward AC, Liongue C, Dobill F, Kumar J, Thompson EW, Quinn MA, Findlay JK et al: Cisplatin treatment of primary and metastatic epithelial ovarian carcinomas generates residual cells with mesenchymal stem cell-like profile. J Cell Biochem 2011.

[37] Balic M, Lin H, Young L, Hawes D, Giuliano A, McNamara G, Datar RH, Cote RJ: Most early disseminated cancer cells detected in bone marrow of breast cancer patients have a putative breast cancer stem cell phenotype. Clin Cancer Res 2006, 12(19):56155621.

[38] Abraham BK, Fritz P, McClellan M, Hauptvogel P, Athelogou M, Brauch H: Prevalence of CD44+/CD24-/low cells in breast cancer may not be associated with clinical outcome but may favor distant metastasis. Clin Cancer Res 2005, 11(3):1154-1159.

[39] Fehm T, Hoffmann O, Aktas B, Becker S, Solomayer EF, Wallwiener D, Kimmig R, Kasimir-Bauer S: Detection and characterization of circulating tumor cells in blood of primary breast cancer patients by RT-PCR and comparison to status of bone marrow disseminated cells. Breast Cancer Res 2009, 11(4):R59. 
[40] Moore RG, Maclaughlan S: Current clinical use of biomarkers for epithelial ovarian cancer. Curr Opin Oncol 2010, 22(5):492-497.

[41] Nakae M, Iwamoto I, Fujino T, Maehata Y, Togami S, Yoshinaga M, Douchi T: Preoperative plasma osteopontin level as a biomarker complementary to carbohydrate antigen 125 in predicting ovarian cancer. J Obstet Gynaecol Res 2006, 32(3):309-314.

[42] Schorge JO, Drake RD, Lee H, Skates SJ, Rajanbabu R, Miller DS, Kim JH, Cramer DW, Berkowitz RS, Mok SC: Osteopontin as an adjunct to CA125 in detecting recurrent ovarian cancer. Clin Cancer Res 2004, 10(10):3474-3478.

[43] Rosen DG, Wang L, Atkinson JN, Yu Y, Lu KH, Diamandis EP, Hellstrom I, Mok SC, Liu J, Bast RC, Jr.: Potential markers that complement expression of CA125 in epithelial ovarian cancer. Gynecol Oncol 2005, 99(2):267-277.

[44] Dai J, Li B, Shi J, Peng L, Zhang D, Qian W, Hou S, Zhao L, Gao J, Cao Z et al: A humanized anti-osteopontin antibody inhibits breast cancer growth and metastasis in vivo. Cancer Immunol Immunother 2010, 59(3):355-366.

[45] Zhao C, Annamalai L, Guo C, Kothandaraman N, Koh SC, Zhang H, Biswas A, Choolani M: Circulating haptoglobin is an independent prognostic factor in the sera of patients with epithelial ovarian cancer. Neoplasia 2007, 9(1):1-7.

[46] Ye B, Cramer DW, Skates SJ, Gygi SP, Pratomo V, Fu L, Horick NK, Licklider LJ, Schorge JO, Berkowitz RS et al: Haptoglobin-alpha subunit as potential serum biomarker in ovarian cancer: identification and characterization using proteomic profiling and mass spectrometry. Clin Cancer Res 2003, 9(8):2904-2911.

[47] Ahmed N, Barker G, Oliva KT, Hoffmann P, Riley C, Reeve S, Smith AI, Kemp BE, Quinn MA, Rice GE: Proteomic-based identification of haptoglobin-1 precursor as a novel circulating biomarker of ovarian cancer. Br J Cancer 2004, 91(1):129-140.

[48] Bertenshaw GP, Yip P, Seshaiah P, Zhao J, Chen TH, Wiggins WS, Mapes JP, Mansfield BC: Multianalyte profiling of serum antigens and autoimmune and infectious disease molecules to identify biomarkers dysregulated in epithelial ovarian cancer. Cancer Epidemiol Biomarkers Prev 2008, 17(10):2872-2881.

[49] Moore RG, Brown AK, Miller MC, Skates S, Allard WJ, Verch T, Steinhoff M, Messerlian G, DiSilvestro P, Granai CO et al: The use of multiple novel tumor biomarkers for the detection of ovarian carcinoma in patients with a pelvic mass. Gynecol Oncol 2008, 108(2):402-408.

[50] Holcomb K, Vucetic Z, Miller MC, Knapp RC: Human epididymis protein 4 offers superior specificity in the differentiation of benign and malignant adnexal masses in premenopausal women. Am J Obstet Gynecol 2011.

[51] Moore RG, Jabre-Raughley M, Brown AK, Robison KM, Miller MC, Allard WJ, Kurman RJ, Bast RC, Skates SJ: Comparison of a novel multiple marker assay vs the Risk of Malignancy Index for the prediction of epithelial ovarian cancer in patients with a pelvic mass. Am J Obstet Gynecol 2010, 203(3):228 e221-226.

[52] Van Gorp T, Cadron I, Despierre E, Daemen A, Leunen K, Amant F, Timmerman D, De Moor B, Vergote I: HE4 and CA125 as a diagnostic test in ovarian cancer: prospective validation of the Risk of Ovarian Malignancy Algorithm. Br J Cancer 2011, 104(5):863-870. 
[53] Jacob F, Meier M, Caduff R, Goldstein D, Pochechueva T, Hacker N, Fink D, Heinzelmann-Schwarz V: No benefit from combining HE4 and CA125 as ovarian tumor markers in a clinical setting. Gynecol Oncol 2011, 121(3):487-491.

[54] Paek J, Lee SH, Yim GW, Lee M, Kim YJ, Nam EJ, Kim SW, Kim YT: Prognostic significance of human epididymis protein 4 in epithelial ovarian cancer. Eur J Obstet Gynecol Reprod Biol 2011.

[55] Rein BJ, Gupta S, Dada R, Safi J, Michener C, Agarwal A: Potential markers for detection and monitoring of ovarian cancer. J Oncol 2011, 2011:475983.

[56] Hassan R, Remaley AT, Sampson ML, Zhang J, Cox DD, Pingpank J, Alexander R, Willingham M, Pastan I, Onda M: Detection and quantitation of serum mesothelin, a tumor marker for patients with mesothelioma and ovarian cancer. Clin Cancer Res 2006, 12(2):447-453.

[57] Scholler N, Fu N, Yang Y, Ye Z, Goodman GE, Hellstrom KE, Hellstrom I: Soluble member(s) of the mesothelin/megakaryocyte potentiating factor family are detectable in sera from patients with ovarian carcinoma. Proc Natl Acad Sci U S A 1999, 96(20):11531-11536.

[58] McIntosh MW, Drescher C, Karlan B, Scholler N, Urban N, Hellstrom KE, Hellstrom I: Combining CA 125 and SMR serum markers for diagnosis and early detection of ovarian carcinoma. Gynecol Oncol 2004, 95(1):9-15.

[59] Simon I, Katsaros D, Rigault de la Longrais I, Massobrio M, Scorilas A, Kim NW, Sarno MJ, Wolfert RL, Diamandis EP: B7-H4 is over-expressed in early-stage ovarian cancer and is independent of CA125 expression. Gynecol Oncol 2007, 106(2):334-341.

[60] Lu KH, Patterson AP, Wang L, Marquez RT, Atkinson EN, Baggerly KA, Ramoth LR, Rosen DG, Liu J, Hellstrom I et al: Selection of potential markers for epithelial ovarian cancer with gene expression arrays and recursive descent partition analysis. Clin Cancer Res 2004, 10(10):3291-3300.

[61] Visintin I, Feng Z, Longton G, Ward DC, Alvero AB, Lai Y, Tenthorey J, Leiser A, Flores-Saaib R, Yu H et al: Diagnostic markers for early detection of ovarian cancer. Clin Cancer Res 2008, 14(4):1065-1072.

[62] Ueland FR, Desimone CP, Seamon LG, Miller RA, Goodrich S, Podzielinski I, Sokoll L, Smith A, van Nagell JR, Jr., Zhang Z: Effectiveness of a multivariate index assay in the preoperative assessment of ovarian tumors. Obstet Gynecol 2011, 117(6):12891297.

[63] Bao LH, Sakaguchi H, Fujimoto J, Tamaya T: Osteopontin in metastatic lesions as a prognostic marker in ovarian cancers. J Biomed Sci 2007, 14(3):373-381.

[64] Matsuura M, Suzuki T, Suzuki M, Tanaka R, Ito E, Saito T: Statin-mediated reduction of osteopontin expression induces apoptosis and cell growth arrest in ovarian clear cell carcinoma. Oncol Rep 2011, 25(1):41-47.

[65] Chang X, Ye X, Dong L, Cheng H, Cheng Y, Zhu L, Liao Q, Zhao Y, Tian L, Fu T et al: Human Epididymis Protein 4 (HE4) as a Serum Tumor Biomarker in Patients With Ovarian Carcinoma. Int J Gynecol Cancer 2011, 21(5):852-858.

[66] Hassan R, Cohen SJ, Phillips M, Pastan I, Sharon E, Kelly RJ, Schweizer C, Weil S, Laheru D: Phase I clinical trial of the chimeric anti-mesothelin monoclonal antibody MORAb-009 in patients with mesothelin-expressing cancers. Clin Cancer Res 2010, 16(24):6132-6138. 
[67] Ho M, Feng M, Fisher RJ, Rader C, Pastan I: A novel high-affinity human monoclonal antibody to mesothelin. Int J Cancer 2011, 128(9):2020-2030.

[68] Kryczek I, Wei S, Zhu G, Myers L, Mottram P, Cheng P, Chen L, Coukos G, Zou W:

Relationship between B7-H4, regulatory $\mathrm{T}$ cells, and patient outcome in human ovarian carcinoma. Cancer Res 2007, 67(18):8900-8905. 


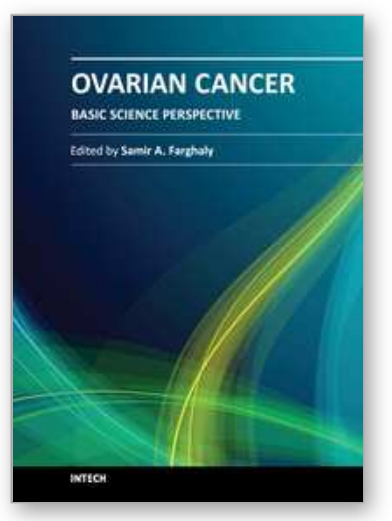

\author{
Ovarian Cancer - Basic Science Perspective \\ Edited by Dr. Samir Farghaly
}

ISBN 978-953-307-812-0

Hard cover, 406 pages

Publisher InTech

Published online 17, February, 2012

Published in print edition February, 2012

Worldwide, Ovarian carcinoma continues to be responsible for more deaths than all other gynecologic malignancies combined. International leaders in the field address the critical biologic and basic science issues relevant to the disease. The book details the molecular biological aspects of ovarian cancer. It provides molecular biology techniques of understanding this cancer. The techniques are designed to determine tumor genetics, expression, and protein function, and to elucidate the genetic mechanisms by which gene and immunotherapies may be perfected. It provides an analysis of current research into aspects of malignant transformation, growth control, and metastasis. A comprehensive spectrum of topics is covered providing up to date information on scientific discoveries and management considerations.

\title{
How to reference
}

In order to correctly reference this scholarly work, feel free to copy and paste the following:

Malgorzata Banys, Natalia Krawczyk and Tanja Fehm (2012). New Tumor Biomarkers in Ovarian Cancer and Its Prognostic and Clinical Relevance, Ovarian Cancer - Basic Science Perspective, Dr. Samir Farghaly (Ed.), ISBN: 978-953-307-812-0, InTech, Available from: http://www.intechopen.com/books/ovarian-cancer-basicscience-perspective/new-biomarkers-and-hematogenous-tumor-cell-dissemination-in-ovarian-cancer

\section{INTECH}

open science | open minds

\section{InTech Europe}

University Campus STeP Ri

Slavka Krautzeka 83/A

51000 Rijeka, Croatia

Phone: +385 (51) 770447

Fax: +385 (51) 686166

www.intechopen.com

\section{InTech China}

Unit 405, Office Block, Hotel Equatorial Shanghai

No.65, Yan An Road (West), Shanghai, 200040, China 中国上海市延安西路65号上海国际贵都大饭店办公楼 405 单元

Phone: +86-21-62489820

Fax: $+86-21-62489821$ 
(C) 2012 The Author(s). Licensee IntechOpen. This is an open access article distributed under the terms of the Creative Commons Attribution 3.0 License, which permits unrestricted use, distribution, and reproduction in any medium, provided the original work is properly cited. 